\title{
POTRET AKTIVITAS BELAJAR, MATERI PELAJARAN DAN SUMBER BELAJAR PENDIDIKAN AGAMA ISLAM SISWA SMAN DAN MAN DI BULUKUMBA
}

\author{
Oleh: \\ Andi Muhammad Asbar \\ Sekolah Tinggi Agama Islam (STAI) Al-Gazali Bulukumba, Sulawesi Selatan \\ e-mail: andimuhammadasbar@gmail.com
}

\begin{abstract}
ABSTRAK
Ruang publik sekolah kini menjadi meriah sejak kehadiran organisasi "Rohis" di lingkungan sekolah dan madrasah. Penulis menjumpai Islamisasi pada ruang publik sekolah, yang kegiatannya cukup aktif di madrasah. Artikel ini bertujuan untuk menjelaskan tiga hal penting, yakni aktivitas belajar, materi pelajaran dan sumber belajar pendidikan Islam siswa SMAN dan MAN di Bulukumba. Dalam penelitian ini, penulis menggunakan pendekatan kualitatif, data dikumpulan dengan metode observasi, wawancara, dan dokumentasi. Selain itu, penulis juga menggunakan reduksi data, setelah itu penyajian data kemudian penarikan kesimpulan sebagai teknik analisis data dalam penelitian. Hasil penelitian ini menunjukkan; pertama; aktivitas belajar pendidikan Islam siswa di SMAN dan MAN berlangsung di dalam dan di luar sekolah. Aktivitas belajar siswa tidak hanya berfokus di sekolah semata, tetapi juga berlangsung di luar sekolah lewat kegiatan tarbiyah, ta'lim, dan halaqah. Aktivitas belajar keagamaan siswa diinspirasi oleh dakwah Islam di sekolah yang diinisiasi oleh "Rohis" sebagai bagian dari organisasi intra sekolah. Kehadiran HILMI (Himpunan Pelajar Muslim) Bulukumba, penulis lihat cukup berkontribusi dalam perkembangan dakwah Islam di sekolah sebagai mitra "Rohis". Kedua, materi yang diminati oleh siswa, tidak terbatas pada pelajaran reguler di sekolah seperti PAI dan Budi Pekerti, Akidah Akhlak, Fikih, Al-Qur'an Hadis dan Sejarah Kebudayaan Islam. Siswa cukup intens menerima suguhan materi "hijrah", dan meteri lainnya yang berkaitan dengan Pendidikan Islam. Ketiga, sumber belajar siswa kenyataannya tidak terbatas lagi pada guru/ustadz, literatur atau buku yang disediakan oleh sekolah. Namun, media sosial telah dimanfaatkan sebagai sumber belajar siswa tentang pendidikan Islam. Hal ini, dapat diidentifikasi melalui penggunaan youtube, facebook, instagram dan WhatsApp.
\end{abstract}

Kata Kunci : aktivitas belajar, materi pelajaran, sumber belajar

Al Qalam: Jurnal Ilmiah Keagamaan dan Kemasyarakatan Vol. 15, No. 2

Juli-Desember 2021 


\section{PENDAHULUAN}

Fenomena Islamisasi pada ruang publik sekolah di Indonesia menarik untuk dicermati, tidak hanya terjadi di kota-kota besar namun hampir merata di berbagai daerah karena perkembangan narasi Islam yang diterima oleh siswa berkat dari media sosial. Ruang publik sekolah ${ }^{1}$, yang dimaksud di sini adalah lingkungan atau situasi di mana warga sekolah berkomunikasi dan berinteraksi secara langsung dan terbuka. Sekolah merupakan salah satu ruang publik, dan berperan sebagai tempat bersemainya kesadaran beragamaan di kalangan pelajar atau siswa. Salah satu organisasi ekstra kurikuler di sekolah, yang mampu menggerakkan hal tersebut bernama 'Rohis' singkatan dari Rohani Islam.

Najib Kailani menggambarkan tentang fenomena dakwah Rohis di sekolah yang dimotori oleh aktivis dakwah tarbiyah. Setidaknya ada tiga strategi yang digunakan untuk terlibat dengan kegiatan sekolah. Pertama, dilakukan melalui jaringan siswa yang aktif dalam kegiatan tarbiyah. Kedua, para aktivis tarbiyah mendekati siswa dari sekolah lain dan mengundang mereka untuk menghadiri pengajian, yang pada gilirannya mendorong para siswa ini untuk meminta izin untuk mendirikan sebuah program Islam di sekolah mereka sendiri. Ketiga, birokrasi sekolah bekerja sama dengan aktivis tarbiyah untuk mengelola program bimbingan Islam mereka. ${ }^{2}$ Namun, dalam studi awal penulis aktivis tarbiyah yang terlibat dalam kegiatan Rohis di Bulukumba bukanlah dari aktivis tarbiyah yang berafiliasi dengan Partai Keadilan Sejahtera (PKS). Melainkan, berafiliasi dengan Organisasi Islam Wahdah Islamiyah, melalui organisasi HILMI (Himpunan Pelajar Muslim Indonesia yang memiliki cabang di Bulukumba.

Selain itu, Islamisasi ruang publik sekolah di Bulukumba juga berdampak pada berkembangnya wacana "hijrah" dikalangan pelajar, tujuan utamanya adalah untuk membuat siswa dan lingkungan mereka menjadi lebih "Islami". Misalnya, termasuk berkembangnya "linguistic piety" dalam komunikasi sehari-hari dari aktivis Rohis, menegakkan sunnah Nabi Muhammad saw, menghindari pacaran dan perayakan hari "valentine" sebagai budaya barat serta menerapkan Islam dalam kehidupan sehari-hari kalangan pelajar.

Di sisi lain, aktivitas belajar siswa juga dipengaruhi oleh penerimaan materi keagamaan melalui salah satu sumber belajar siswa melalui media sosial. Hal ini merujuk pada intensitas dan penerimaan wacana-wacana keagamaan lewat sosial media utamanya aplikasi youtube, di mana siswa dapat mengakses bahan-bahan materi keagamaan lewat ustadz "digital friendly" yang mereka sukai atau senangi sesuai passion mereka sebagai anak muda yang tidak bisa lepas dari ponsel pintar (smart phone).

${ }^{1}$ Lihat Suhadi, et al., Politik Pendidikan Agama: Kurikulum 2013 dan Ruang Publik Sekolah (Yogyakarta: Serial Laporan Kehidupan Beragama di Indonesia CRCS UGM, 2014), 44.

${ }^{2}$ Ahmad Norma Permana \& Najib Kailani, Islam and the 2009 Indonesia Elections, Political and Cultural Issues: The Case of the Prosperous Justice Party (PKS) (Bangkok: IRASEC, 2010), 91.

Al Qalam: Jurnal Ilmiah Keagamaan dan Kemasyarakatan Vol. 15, No. 2 Juli-Desember 2021 
Bagi Oemar Hamalik, hal yang perlu diamati terkait dengan aktivitas siswa dalam belajar yang termasuk memperlajari agama Islam. Pertama, siswa adalah suatu organisme yang hidup, dan memiliki prinsip aktif atau keinginan untuk berbuat dan bekerja sendiri. Kedua, siswa memiliki kebutuhan, meliputi kebutuhan jasmani, rohani, dan sosial. Dengan sendirinya, aktivitas kegiatan akan semakin banyak dan juga beragam variasi karena kebutuhan yang telah berubah atau bertambah untuk tujuan tertentu. ${ }^{3}$

Melihat ini sebagai potensi untuk dikembangkan, maka tugas guru adalah berusaha untuk memaksimalkan manfaat teknologi sekaligus mencegah dan meminimalkan dampak-dampak negatifnya. ${ }^{4}$ Dampak yang dimaksud adalah, internet menjadi komoditi bagi kelompok tertentu untuk menularkan ideologinya, sehingga perlu perhatian serius atau justru kehadiran media sosial dan ruang yang lainnya menghadirkan ruang baru yang menciptakan kesalehan pada pelajar di SMA dengan konten-konten keislaman yang lebih populer.

Di kalangan pelajar SMA di Bulukumba, hadir komunitas yang mengatasnamakan diri dengan komunitas "JOFIS" (singkatan dari jomblo fii sabilillah), sejatinya ini bentuk gerakan anti pacaran sekaligus identitas "hijrah" yang menjadi tren di kalangan pelajar muslim. Komunitas ini aktif memanfaatkan sosial media untuk belajar keislaman. Tampaknya, komunitas ini tampaknya tidak hadir secara alamiah, tanpa ada motif tertentu yang melatarinya.

Artikel ini bermaksud untuk menjelaskan fenomena tersebut di atas, dengan fokus mendeskripsikan tentang aktivitas belajar, materi pelajaran yang siswa sekolah dan madrasah terima, dan bentuk-bentuk sumber belajar siswa SMAN dan MAN di Bulukumba.

\section{METODE PENELITIAN}

Dalam artikel ini, penulis akan menjelaskan 3 (tiga) bagian utama yang menjadi objek penting di balik mencuatnya gejala Islamisasi ruang publik sekolah di Bulukumba, dengan memotret aktivitas belajar, materi pelajaran dan sumber belajar pendidikan agama Islam siswa di SMAN dan MAN di Bulukumba.

Penelitian ini menyasar empat objek riset yang terdiri dari SMAN 1 Bulukumba, SMAN 8 Bulukumba, MAN 1 Bulukumba dan MAN 2 Bulukumba. Informan dalam penelitian ini dipilih berdasarkan teknik purposive sampling, yang mana informan yang menjadi sumber data betul-betul memahami problem riset yang sedang ingin dijawab oleh peneliti. peneliti juga menggunakan snowball sampling, teknik ini membantu peneliti untuk mengidentifikasi informan berdasarkan petunjuk, atau informasi dari narasumber sebelumnya.

Sedangkan, teknik pengumpulan data dalam riset ini, menggunakan metode observasi, wawancara dan dokumentasi. Dalam penelitian ini menggunakan analisis data

${ }^{3}$ Lihat Oemar Hamalik, Proses Belajar Mengajar (Cet. IV; Jakarta: Bumi Aksara, 2005), 170-171.

${ }^{4}$ Lihat kata pengantar Mujiburrahman "Mendidik Generasi Elektronik" dalam Raihani, Pendidikan Islam dalam Masyarakat Multikultural (Yogyakarta: Pustaka Pelajar, 2016), xiv.

Al Qalam: Jurnal Ilmiah Keagamaan dan Kemasyarakatan Vol. 15, No. 2 Juli-Desember 2021 
model Miles and Huberman, yang terdiri dari tiga komponen, yaitu data reduction, data display, dan conclusion drawing/verification. ${ }^{5}$ Pertama, data reduction (reduksi data) adalah suatu bentuk analisis yang menajamkan, menggolongkan, membuang yang tak perlu, dan mengorganisasikan data sedemikian rupa sehinggga diperoleh kesimpulan akhir dan diverifikasi. Laporan-laporan direduksi, dirangkum, dipilih hal-hal pokok, difokuskan mana yang penting dicari tema atau polanya dan disusun lebih sistematis. ${ }^{6}$ Reduksi data berlangsung terus menerus selama penelitian berlangsung. Peneliti mengumpulkan semua hasil penelitian berupa hasil wawancara, dokumentasi, hasil observasi yang berkaitan dengan fokus penelitian. Selanjutnya, data disederhanakan dan disajikan dengan cara mendeskripsikan dalam bentuk paparan data secara naratif.

Kedua, setelah data direduksi, selanjutnya peneliti ke tahap data display (penyajian data). Dalam penelitian ini penyajian data dilakukan dalam bentuk uraian singkat, yang paling sering digunakan untuk menyajikan data dalam penelitian kualitatif adalah dengan teks yang bersifat naratif dari catatan lapangan. Penyajian data adalah tahapan untuk memahami apa yang sedang terjadi dan apa yang harus dilakukan selanjutnya. Tujuannya untuk dianalisis dan diambil tindakan yang dianggap perlu. Metode penyajian data dengan menggunakan metode mengidentifikasi data, mengklasifikasikan data dan menggeneralisasi terhadap data yang telah direduksi. Teknik ini digunakan oleh peneliti untuk memperoleh data yang betul-betul akurat, obyektif, valid dan berkualitas. Teknik ini nantinya juga akan membantu peneliti.

Setelah penyajian data terlaksana, berlanjut pada tahap ketiga yaitu conclusion drawing/verification atau pengambilan kesimpulan dan verifikasi. Tahap ini melibatkan peneliti dalam proses interpretasi dan penetapan makna dari data yang tersaji. Kesimpulan dalam penelitian kualitatif ini menjawab rumusan masalah yang dirumuskan sejak awal.

\section{HASIL PENELITIAN DAN PEMBAHASAN}

\section{Aktivitas Belajar Pendidikan Islam Siswa SMAN dan MAN di Bulukumba}

Aktivitas belajar terjadi dalam satu konteks untuk mencapai sesuatu perubahan tertentu serta menggunakan seluruh potensi individu (siswa) sehingga akan terjadi perubahan perilaku tertentu. Menurut Rusman, dalam pembelajaran siswa perlu mendapatkan kesempatan untuk melakukan aktivitas. Aktivitas belajar memiliki ciri, yaitu terjadi secara sadar, bersifat fungsional, positif, aktif, dan tidak bersifat sementara. Cirinya merujuk pada perubahan tingkah laku, dan untuk mencapai perubahan tersebut dilakukan dengan berbagai cara. ${ }^{7}$

\footnotetext{
${ }^{5}$ Mattew B. Milles and A. Michael Huberman, Qualitative Data Analysis: A Sourcebook Of NewMethods (London: Sage Publication, 1984), 21-23.

${ }^{6}$ Nasution, Metode Penelitian Naturalistik Kualitatif (Bandung: Tarsito, 2003), 129.

${ }^{7}$ Rusman, Belajar dan Pembelajaran: Berorientasi Standar Proses Pendidikan (Jakarta: Pranadamedia Group, 2017), 90.
}

Al Qalam: Jurnal Ilmiah Keagamaan dan Kemasyarakatan Vol. 15, No. 2 Juli-Desember 2021 
Penulis menemukan, bentuk aktivitas belajar siswa di SMAN 1 Bulukumba, SMAN 8 Bulukumba, MAN 1 Bulukumba dan MAN 2 Bulukumba dapat dilihat dalam dua kategori berdasarkan tempatnya, yaitu aktivitas belajar yang berlangsung di sekolah, dan aktivitas belajar yang berlangsung di luar sekolah utamanya yang berkaitan dengan aktivitas belajar pendidikan Islam. Inilah yang akan penulis uraikan sebagai gambaran aktivitas belajar tentang pendidikan Islam di kalangan siswa atau peserta didik.

\section{Sekolah}

Aktivitas belajar Pendidikan Islam secara normatif yang berlangsung di sekolah atau madrasah, memiliki tujuan untuk menumbuhkan dan meningkatkan keimanan melalui pemberian dan pemupukan pengetahuan, penghayatan, pengamalan, serta pengalaman peserta didik tentang agama Islam sehingga menjadi manusia muslim yang terus berkembang dalam hal keimanan, ketakwaannya, berbangsa dan bernegara, serta untuk dapat melanjutkan pada jenjang yang lebih tinggi. ${ }^{8}$

Aktivitas belajar pendidikan Agama Islam pada jenjang Sekolah Menengah Atas (SMA) dan Madrasah Aliyah (MA), memiliki perbedaan yang sangat mencolok. Pertama, siswa di tingkat SMA belajar mata pelajaran Pendidikan Agama Islam dan Budi Pekerti. PAI dan Budi Pekerti di SMA, sama posisinya dengan mata pelajaran umum yang lain yang ada di Sekolah, seperti Matematika, Bahasa Indonesia, PPKN, Biologi, Fisika dan mata pelajaran lainnya. Jumlah jam mata pelajaran PAI dan Budi Pekerti adalah 3 (tiga) jam pelajaran, sebelum kurikulum 2013 diberlakukan mata pelajaran Pendidikan Agama Islam hanya diajarkan 2 (dua) jam. Kedua, di jenjang madrasah muatan pembelajaran pendidikan agama Islam lebih banyak daripada di jenjang SMA, di antaranya adalah AlQur'an Hadis, Akidah Akhlak, Fikih dan Sejarah Kebudayaan Islam. Masing-masing mata pelajaran diajarkan selama 2 jam pelajaran baik di kelas X, XI dan XII.

Hal ini relevan dengan apa yang diungkap oleh Rohmat Mulyana, bahwa struktur kurikulum yang berlaku di Indonesia Pendidikan Agama Islam (PAI) dimaknai dalam dua sisi: 1) PAI dipandang sebagai mata pelajaran, sebagaimana yang ada pada kurikulum PAI pada sekolah umum (SD, SMP, SMA/K). 2) PAI dipandang sebagai rumpun mata pelajaran seperti Qur'an hadits, fiqh, aqidah akhlak, sejarah kebudayaan Islam, sebagaimana pada kurikulum pendidikan pada madrasah. ${ }^{9}$

Empat sekolah yang menjadi objek penelitian penulis di Bulukumba, pada umumnya telah menggunakan kurikulum 2013. Aktivitas belajar siswa, diarahkan untuk mencapai 4 (empat) kompetensi inti yang menjadi perintah dari kurikulum 2013. Dalam kurikulum $2013^{10}$ ada perubahan mencolok berkaitan dengan pendidikan Islam di SMA,

\footnotetext{
${ }^{8}$ Abdul Majid dan Dian Andayani, Pendidikan Agama Islam Berbasis Kompetensi (Bandung: PT Rosdakarya, 2005), 135.

${ }^{9}$ Rohmat Mulyana, Mengartikulasikan Pendidikan Nilai (Bandung: Alfabeta, 2004), 198.

${ }^{10}$ Ada alasan mengapa pemerintah menyusun kurikulum 2013, yaitu 1) Kurikulum KTSP dianggap memberikan otonomi terlalu besar kepada sekolah; 2) Isi kurikulum KTSP dianggap terlalu padat itu ditujukkan dengan banyaknya mata pelajaran dan banyaknya materi yang tingkat kesulitannya melampaui perkembangan usia peserta didik; 3) Kurikulum KTSP dianggap belum sepenuhnya berbasis kompetensi
}

Al Qalam: Jurnal Ilmiah Keagamaan dan Kemasyarakatan Vol. 15, No. 2 Juli-Desember 2021 
yaitu pertama, penambahan kata "Budi Pekerti" dalam mata pelajaran Pendidikan Agama Islam (PAI) yang kemudian berubah nama menjadi PAI dan Budi Pekerti. Kedua, waktu/durasi belajar dari 2 jam menjadi 3 jam untuk pembelajaran PAI dan Budi Pekerti.

Aktivitas belajar pendidikan Agama Islam di kelas, diharapkan mampu mengembangkan empat Kompetensi Inti (KI) pada siswa begitu juga pada mata pelajaran lainnya, yakni KI 1: Kompetensi Spiritual, KI 2: Kompetensi Sosial, KI 3: Kompetensi Pengetahuan, dan KI 4: Kompetensi Keterampilan. Aktivitas belajar agama Islam di kelas sebagaimana yang termuat dalam Kurikulum 2013 pada dasarnya cenderung prosedural, mulai dari kegiatan input, proses dan output. Harapannya empat kompetensi inti sebagaimana tunturan kurikulum 2013, dapat dicapai dengan segala perangkat yang disedikan oleh Kementerian Pendidikan dan Kebudayaan serta Kementerian Agama. Menurut Asdar ${ }^{11}$, pendidikan agama Islam di sekolah yang kita harapkan hanya beberapa jam saja, yaitu 3 (tiga) jam mata pelajaran saja. Tidak mencukupi untuk membimbing seluruh aspek-aspek sesuai dengan tujuan pendidikan itu.

Selanjutnya, penulis menjelaskan bagaimana aktivitas belajar keagamaan siswa utamanya di SMAN 1 Bulukumba, SMAN 8 Bulukumba, MAN 1 Bulukumba dan MAN 2 Bulukumba yang berlangsung di luar kelas. Menulis melakukan kategorisasi, yaitu aktivitas belajar yang diikuti oleh siswa pada jenjang SMA dan MAN di Bulukumba.

\section{a. SMAN 1 Bulukumba dan SMAN 8 Bulukumba}

Di SMAN 1 Bulukumba dalam penuturan Andi Akram Bakti, bahwa setiap hari Jumat di sekolah kita mengadakan kegiatan "Tadarrus Al-Qur'an" kita mengaji bersama di dalam mesjid sekolah. Karena mesjid kecil, jadi dijadwal setiap angkatan dalam setiap minggunya. ${ }^{12}$ Tidak hanya itu saja dirinya juga aktif dalam organisasi Rohis. Rohis memiliki program yang bertujuan untuk meningkatkan ketakwaan siswa. Bentuknya seperti Tablik Akbar. Hal yang sama juga dituturkan oleh Sri Rabiatul ${ }^{13}$, bahwa dirinya aktif sebagai pengurus Rohis juga ikut dalam kegiatan Tabligh Akbar yang dilakukan di Sekolah.

Akram juga menjelaskan bahwa lewat Rohis, mereka belajar meningkatkan kemampuan mengaji, terkait tentang makhraj, atau hukum bacaan dalam al-Qur'an. ${ }^{14}$ Selain aktif di lembaga Rohis di SMAN 1 Bulukumba, banyak juga anggota Rohis yang aktif di organisasi pelajar seperti HILMI (Himpunan Pelajar Muslim) Bulukumba

sebagaimana yang diatur dalam fungsi dan tujuan pendidikan Nasional. Lihat Suhadi, et al., Politik Pendidikan Agama: Kurikulum 2013 dan Ruang Publik Sekolah, (Yogyakarta: Serial Laporan Kehidupan Beragama di Indonesia CRCS UGM, 2014), 22-25.

${ }^{11}$ Wawancara dengan Asdar S,Pd., M.Pd., Pembina Rohis SMAN 8 Bulukumba, pada tanggal 09 April 2019 di SMAN 8 Bulukumba

${ }^{12}$ Wawancara dengan Andi Akram Bakti, Pengurus Rohis SMAN 1 Bulukumba pada tanggal 22 April 2019 bertempat di Mesjid Sekolah.

${ }^{13}$ Wawancara dengan Sri Rabiatul, siswa Kelas XI MIA 6 SMAN 1 Bulukumba pada tanggal 22 April 2019 bertempat di Lingkungan Sekolah.

${ }^{14}$ Wawancara dengan Andi Akram Bakti, tanggal 22 April 2019 di Mesjid Sekolah.

Al Qalam: Jurnal Ilmiah Keagamaan dan Kemasyarakatan Vol. 15, No. 2 Juli-Desember 2021 
untuk ikhwan, sedangkan untuk akhwat itu aktif di IPMI Bulukumba. Informasi ini penulis ketahui dari Akram.

Sedangkan, di SMAN 8 Bulukumba, salah seorang siswa bernama Abdi mengatakan bahwa dirinya ikut kegiatan pengajian dari Rohis. Materi yang pernah diikutinya, yaitu tentang menjadi pribadi yang lebih baik. ${ }^{15}$ Begitu pula dengan apa dikatakan oleh Nisa bahwa bergabung sebagai anggota rohis karena saat kelas X. Materi yang diikuti, biasanya itu tentang "berhijrah", "belajar caramah" dan "bahasa arab". 16

Kegiatan Rohis di SMA 8 Bulukumba, bertujuan meningkatkan keimanan, ketakwaan dan akhlak peserta didik, agar sama dengan tujuan pendidikan Nasional. Dalam pembinaan Rohis di SMAN 8 bulukumba, khusus untuk akhwat itu dibina oleh guru agama perempuan, sedangkan khusus ikhwan dibina oleh guru laki-laki. ${ }^{17}$

Nogroho Budianto, mengatakan Rohis adalah organisasi yang menjalankan aktivitas dakwah di sekolah, ada tiga alasan yang melatari pentingnya dakwah sekolah, yaitu: 1) efektif, menanamkan aqidah dan moralitas kepada remaja dan pemuda adalah jauh lebih efektif daripada berdakwah kepada golongan tua yang sarat dengan kontaminasi kepentingan pragmatis dan ideologis. 2) masif, dikatakan masif karena jumlah populasi pelajar sangat banyak dan tersebar di seluruh pelosok Indonesia. Pengaruh dakwah sangat besar dalam segmen pelajar. 3) strategis, karena dakwah sekolah dalam jangka panjang akan mensuplai SDM yang saleh di berbagai lapisan masyarakat sekaligus. ${ }^{18}$

Dapat disimpulkan bahwa aktivitas belajar tentang Islam di lingkungan sekolah itu dilakukan di dalam kelas dan di luar kelas. Belajar agama Islam di dalam kelas, yaitu mengikuti tuntutan kurikulukum, sedangkan belajar agama Islam seperti kegiatan keagamaan tetapi masih tetap di lingkungan sekolah itu bagian dari kebijakan yang ada di sekolah tersebut. Serta, saling terintegrasi satu sama lainnya, tentunya untuk menunjang pembelajaran PAI di sekolah.

\section{b. MAN 1 Bulukumba dan MAN 2 Bulukumba}

Penulis menemukan perbedaan nama sebagai lembaga ektrakurikuler keagamaan di MAN 1 dan MAN 2 Bulukumba. Kalau di MAN 1 Bulukumba pihak sekolah mengunakan nama "SISPAIS" singkatan dari (Siswa Pecinta Agama Islam). Sedangkan, untuk MAN 2 Bulukumba menggunakan istilah "Rohis".

\footnotetext{
${ }^{15}$ Wawancara dengan Abdi, Siswa Kelas X IS SMAN 8 Bulukumba pada tanggal 05 April 2019 bertempat di lingkungan sekolah.

${ }^{16}$ Wawancara dengan Nisa, Siswa Kelas X MIA SMAN 8 Bulukumba pada tanggal 09 April 2019 bertempat di ruang kelas.

${ }^{17}$ Setelah kita lakukan itu, dampaknya sangat signifikan sekali. dulunya mesjid tidak terlalu penuh, sekarang Alhamdulillah. Sekarang guru di sekolah aktif mengkampanyekan yang diprioritaskan untuk kegiatan agama kita. Dulu kegiatan-kegiatan mengaji itu sepi, sekarang ramai sekali. Peserta didik mau belajar tahsim Al-Qur'an. Wawancara dengan Asdar S,Pd., M.Pd., pada tanggal 09 April 2019 di SMAN 8 Bulukumba

${ }^{18}$ Nogroho Widiantoro, Panduan Dakwah Sekolah, Kerja Besar untuk Perubahan Besar (Bandung: Syaamil Cipta Media, 2003), 29-31.
}

Al Qalam: Jurnal Ilmiah Keagamaan dan Kemasyarakatan Vol. 15, No. 2 Juli-Desember 2021 
Menurut Zaenal, bahwa di MAN 1 Bulukumba ini dibentuk lembaga ekstrakurikuler bernama "SISPAIS" yang bekerjasama dengan OSIS (Organisasi Intra Sekolah), "SISPAIS" ini sudah lama digunakan oleh sekolah sebelum saya pindah ke sekolah ini sekitar 6 tahun lalu. Kita tidak gunakan nama "Rohis", salah satu kegiatannya apalagi menjelang ramadhan adalah "Pesantren Ramadhan" kita juga melatih siswa untuk ceramah, kemudian diutus untuk mengisi ceramah diluar sekolah membawa nama sekolah. ${ }^{19}$

Sedangkan, menurut Yudha Purnama siswa Kelas X MIA 2 MAN 1 Bulukumba, menegaskan bahwa ia aktif dalam kegiatan "SISPAIS", kegiatan-kegiatan yang sering diikutinya adalah shalat dhuha, tilawah, ceramah agama lewat kegiatan "Jumat Tazkirah". Bagi Yudha, SISPAIS adalah organisasi yang melibatkan siswa untuk memajukan dirinya untuk beragama dan membantu siswa untuk lebih baik lagi dalam hal agama. ${ }^{20}$

Berbeda halnya, dengan Ahmad Faizal. Ia menuturkan bahwa kegiatan yang biasa diikuti di sekolah adalah "Al-Qur'an Camp" kegiatan ini diadakan setiap rapat OSIS. Biasanya setiap hari Selasa dan Jumat. Kegiatan ini khusus untuk pengurus OSIS. Tekniknya, salah seorang pengurus ditunjuk untuk memimpin pembacaan AlQur'an. ${ }^{21}$

Berbeda halnya, dengan kegiatan keagamaan yang berlangsung di lingkungan Sekolah MAN 2 Bulukumba yang terletak di pusat kota Bulukumba. Kegiatan keagamaan di MAN 2 Bulukumba, banyak digerakkan oleh pengurus Rohis. Menurut Arsy bahwa dalam kajian yang dilaksanakan oleh pengurus Rohis yang selalu kami undang itu dari kalangan Wahdah Islamiyah Bulukumba soalnya mereka yang sering melakukan kajian rutin di sini yang lain tidak. Jadi, kalau ada kajian ke Wahdah. ${ }^{22}$

Kegiatan Rohis MAN 2 Bulukumba, dikemas dalam bentuk kegiatan "Tabligh Akbar". Seringkali kegiatan mereka kerjasamakan dengan organisasi pelajar yang bernama HILMI Bulukumba. HILMI ini, merupakan sayap organisasi dari Wahdah Islamiyah di Bulukumba.

Kegiatan Rohis MAN 2 Bulukumba, memiliki banyak kegiatan yang penulis tidak temukan dalam organisasi Rohis di SMAN 1 Bulukumba, SMAN 8 Bulukumba. Menurut Farhan bahwa kegiatan Rohis di MAN 2 Bulukumba, meliputi beberapa hal yakni, mabit, tarbiyah, ta'lim. Dalam kegiatan tarbiyah dan ta'lim biasanya bermalam

\footnotetext{
${ }^{19}$ Wawancara dengan Zaenal, S.Pd.I, Pembina SISPAIS MAN 1 Bulukumba, pada tanggal 25 April 2019 di Ruang Guru

${ }^{20}$ Wawancara dengan Yudha Purnama, siswa kelas X MIA 2 MAN 1 Bulukumba pada tanggal 25 April 2019 bertempat di lingkungan sekolah.

${ }^{21}$ Wawancara dengan Ahmad Faizal, siswa kelas X MIA 2 MAN 1 Bulukumba pada tanggal 25 April 2019 bertempat di lingkungan sekolah.

${ }^{22}$ Wawancara dengan Arsy, pengurus Rohis MAN 2 Bulukumba pada tanggal 27 Maret 2019 di Mesjid Miftahul Ulum Jl. Matahari Bulukumba
}

Al Qalam: Jurnal Ilmiah Keagamaan dan Kemasyarakatan Vol. 15, No. 2 Juli-Desember 2021 
di mesjid, yaitu pada malam rabu, dan malam jumat. ${ }^{23}$ Sedangkan, "mabit" adalah salah satu dari program kerja Rohis MAN 2 Bulukumba yang kegiatannya diawali dengan "Tahsinul Qur'an" dan dilanjutkan dengan shalat isya berjamaah serta taujihat dari Ustadz Saifullah. Mabit dipandang sebagai sarana penguatan $u k h u w a h$, bertujuan agar pengurus Rohis menjadi qudwah dan cerminan bagi siapapun yang ada disekitarnya. ${ }^{24}$

Di sekolah yang menjadi objek riset penulis selain dari MAN 1 Bulukumba, organisasi ekstrakurikuler, seperti "Rohis" (Rohani Islam) itu menjadi primadona di kalangan siswa di Bulukumba. Namun, menjadi penting untuk diketahui adalah bangkitnya kegiatan "Rohis" di sekolah itu tidak terlepas dari peran organisasi HILMI Bulukumba. Organisasi pendatang baru ini, boleh dikatakan masih seumur jagung yang kepengurusannya dibentuk pada tanggal 26 Agustus $2018 \mathrm{M} / 14$ Dzulhijjah $1439 \mathrm{H}^{25}$

Organisasi HILMI Bulukumba telah membina 9 sekolah dari 17 Sekolah di Bulukumba baik SMAN dan MAN. Mereka juga telah mengklaim dominasi dakwah sekolah di Bulukumba. Organisasi pelajar ini, telah menjadi primadona karena berhasil menghadirkan ruang kajian keagamaan di sekolah lewat kerjasama dengan Organisasi Rohis. Tentu dengan branding organisasi yang mapan, serta tema-tema kajian yang lebih kontekstual membahas masalah-masalah yang sedang dihadapi oleh remaja milenial di Bulukumba. peran HILMI Bulukumba, cukup mendominasi dakwah Islam di sekolah, serta menunjukkan kegiatan pengorganisasian dan manajemen yang relatif baik.

\section{Luar Sekolah}

Aktivitas belajar agama siswa di Bulukumba, pada dasarnya tidak hanya berlangsung di lingkungan sekolah tetapi aktivitas atau kegiatan itu juga berlangsung di luar sekolah. Setidaknya ada lima jenis kegiatan kajian tentang keagamaan yang diikuti oleh siswa dengan beragam bentuk, antara lain, yaitu tabligh akbar, tarbiyah, ta'lim, halaqah dan komunitas Jofis (Jomblo Fii Sabilillah).

Pertama, tabligh akbar. Ini merupakan menjadi salah satu jenis kegiatan pengajian yang cukup menarik perhatian dari kalangan siswa. Kegiatan ini, terkadang diinisiasi oleh organisasi keagamaan di sekolah sehingga siswa dapat terlibat langsung seperti yang dilakukan oleh Rohis SMAN 1 Bulukumba, dengan mengundang penceramah dari luar. Begitu juga yang pernah dilakukan oleh MAN 2 Bulukumba. Siswa juga sering kali mengikuti kegiatan tabligh akbar yang dilakukan di luar sekolah, karena sekolah

${ }^{23}$ Di kegiatan "tarbiyah" itu, kita dibina menjadi seorang muslim yang sejati secara kaffah. Karena, banyak yang jadi muslim hanya karena keturunan saja. Saat kajian, tema yang diangkat itu materi umum kak, tergantung teman-teman seperti apa pertanyannya. Sedangkan, kegiatan "ta'lim" materinya juga umum saja. Terserah apa yang di inginkan oleh teman-teman. Kalau pengajian "ta'lim" yang biasa saya ikuti kajian kitab seperti Kitab Al-Muwwatta’ karya Imam Malik. Wawancara dengan Farhan, pada tanggal 27 Maret 2019 di Mesjid Miftahul Ulum Jl. Matahari Bulukumba

${ }^{24}$ Lihat kegiatan "Mabit" Rohis MAN 2 Bulukumba dalam https://hilmi.or.id/melalui-mabit-rohisman-2-bulukumba-bentuk-generasi-pelanjut/ (Diakses pada tanggal 30 Maret 2019).

${ }^{25}$ Lihat acara pengukuhan organisasi PD HILMI Bulukumba di https://hilmi.or.id/allahu-akbarribuan-peserta-padati-tabligh-akbar-sekaligus-pengukuhan-pengurus-pd-hilmi-bulukumba/ (Diakses pada tanggal 30 Maret 2019).

Al Qalam: Jurnal Ilmiah Keagamaan dan Kemasyarakatan Vol. 15, No. 2 Juli-Desember 2021 
mendapatkan undangan untuk mengikuti kegiatan kegiatan tersebut. Seperti, kegiatan tabligh akbar yang dilakukan oleh Bikers Muslim Bulukumba, tabligh akbar yang dilakukan oleh pengurus HILMI Bulukumba yang mengundang organisasi Rohis di Bulukumba. Tema yang tren dan sering kali diulas dalam kegiatan tabligh akbar ini adalah tentang "Hijrah", hijrah kemudian menjadi wacana cosmopolitan yang menyasar berbagai kalangan utamanya adalah kalangan remaja atau anak muda. Hijrah, juga adalah materi yang sangat banyak diungkap oleh siswa dalam pembahasan materi yang seringkali diterima oleh peserta didik baik di sekolah maupun di luar sekolah. Hijrah, kemudian menimbulkan beragam penafsiran di kalangan pelajar di Bulukumba, yang secara spesfik penulis uraikan di pembahasan selanjutnya tentang materi keagamaan yang sering diterima oleh siswa.

Kedua yaitu halaqah. Penulis menemukan siswa yang giat melakukan kajian keagamaan dalam bentuk halaqah mereka membaca kitab Fadhilah Amal. Yang mana salah seorang siswa membacakan isi kitab tersebut kemudian dijadikan sebagai bahan renungan bagi mereka. Aktivitas di atas penulis temukan, setelah shalat berjamaah Dzuhur di Mesjid Taqwa Tanete di samping MAN 1 Bulukumba. Informasi yang disampaikan Ahmad Rafiq, bahwa kegiatan ini rutin dilakukan oleh siswa tersebut. Dalam hemat penulis, Kitab Fadhilah Amal yang dibacakan oleh siswa itu merupakan karangan dari Syaikh Muhammad Zakariyah Al-Kandahlawi salah seorang tokoh dari Jamaah Tabligh. Kitab ini juga menjadi rujukan dari aktivitas dakwah yang dilakukan oleh "Jamaah Tabligh", Asumsi penulis, siswa yang membacakan kitab itu pernah mengikuti aktivitas khuruj' sebuah perjalanan dakwah yang dilakukan oleh kalangan jamaah tabligh. Hal itu penulis identifikasi dari pakaian yang digunakan oleh siswa yang pakaiannya berbeda dengan siswa lainnya. Padahal itu masih dalam waktu jam isterahat siswa, yang umumnya digunakan untuk kegiatan shalat berjamaah di Mesjid tersebut.

Ketiga, tarbiyah. Beberapa informan penulis, menyebutkan bahwa aktivitas belajar agama mereka di luar sekolah lewat "tarbiyah". Hal itu diungkap oleh Farhan ${ }^{26}$, bahwa mereka mengikuti kegiatan tarbiyah pada malam rabu di Masjid Miftahul Ulum sebuah sekolah di lingkungan MAN 2 Bulukumba yang digunakan oleh masyarakat sekitar untuk shalat berjamaah. Kegiatan ini diinisiasi oleh Rohis digandengkan dengan kegiatan Mabit (bermalam), namun tidak semua pengurus Rohis mengikuti kegiatan ini. Hanya bagi mereka yang mau saja, dan mendapat izin dari orang tuanya. Senada dengan Farhan, seorang pelajar bernama Sri Rabiatul ${ }^{27}$ juga menuturkan bahwa dirinya juga sering mengikuti "Tarbiyah" yang dilakukan oleh organisasi Wahdah Islamiyah.

Keempat, ta'lim. Farhan menuturkan bahwa mereka juga sering mengikuti kegiatan ta'lim yang dilakukan oleh pengurus Rohis di Mesjid Miftahul Ulum pada malam jumat. Kegiatan ini sifatnya tidak wajib bagi pengurus Rohis. Bagi Farhan sendiri ia, seringkali

\footnotetext{
${ }^{26}$ Wawancara dengan Farhan, pada tanggal 27 Maret 2019 di Mesjid Miftahul Ulum Jl. Matahari Bulukumba

${ }^{27}$ Wawancara dengan Sri Rabiatul, pada tanggal 22 April 2019 bertempat di Lingkungan Sekolah.
}

Al Qalam: Jurnal Ilmiah Keagamaan dan Kemasyarakatan Vol. 15, No. 2 Juli-Desember 2021 
juga mengikuti kajian ta'lim di Mesjid Arrahmah bertempat di Jalan Merpati Bulukumba. Sri Rabiatul ${ }^{28}$ juga, mengikuti kegiatan ta'lim setiap hari senin di Mesjid Arrahmah.

Kelima, dakwah ala komunitas Jofis. Salah satu komunitas yang jumlah anggotanya sekitar 25 orang yang terdiri dari kalangan pelajar di SMA di Bulukumba. Hal Ini kemudian menjadi menarik perhatian penulis. Dalam wawancara dengan Andi Ainun ${ }^{29}$, diulas bahwa motivasi pembentukan Jofis ini, adalah berawal gagasan dari seorang penulis Laode Munafar dalam bukunya "Indonesia Tanpa Pacaran". Sebenarnya Indonesia tanpa pacaran sudah sampai di Propinsi, tapi belum ada di daerah sehingga kami belum menyambung komunikasi ke Propinsi. Hanya perkumpulan-perkumpulan kecil dengan teman untuk mengajak teman kepada kebaikan maka terbentuklah Jofis ini. Hanya sebuah forum atau diskusi umumlah dengan teman-teman untuk sharing ilmu.

Lanjut Ainun, dikatakan bahwa tujuan awal dari komunitas ini adalah menjadi jomblo yang berada di jalan Allah. Prinsip kami tidak pacaran sampai menikah atau halal. Satu syarat yang diimplementasikan, yaitu tidak boleh pacaran. Kalau ada teman yang diketahui memiliki "hubungan khusus" dengan cowok. Kami nasehati untuk tidak berpacaran. ${ }^{30}$

Aktivitas kajian keagamaan di komunitas Jofis ini, aplikasi Whatsapp (WA). Kajian dilakukan setiap hari rabu, yang akan menjadi pemateri kajian itu ditentukan mirip dengan arisan, kemudian setiap kajian di ikuti dengan tanya jawab. Ia juga aktif di media sosial lainnya seperti instagram untuk mendakwahkan gerakan anti pacaran di kalangan remaja.

Data penelitian di atas, menunjukkan bahwa aktivitas belajar yang berlangsung pada kalangan siswa atau pelajar, khususnya pada 4 (empat) sekolah/madrasah di Bulukumba ada dua hal, yakni aktivitas belajar yang berlangsung di lingkungan sekolah dan di luar lingkungan sekolah.

Aktivitas belajar yang terjadi di lingkungan sekolah, telah mengarah kepada bentuk "Islamisasi Ruang Publik Sekolah". Itu dipengaruhi oleh gerakan dakwah sekolah yang dipelopori oleh organisasi Rohis. Najib Kailani, mengatakan bahwa Rohis telah menjadi sebuah alternatif dalam kehidupan remaja Muslim di Indonesia, karena merebaknya "moral panics" di Indonesia. Popularitas Rohis di kalangan pelajar Muslim berkaitan dengan krisis identitas dalam kehidupan pelajar yang banyak dipengaruhi oleh budaya pop Barat. Eksistensi dari Rohis di sekolah, seperti "oasis" bagi para pelajar yang tengah mencari identitas diri mereka di tengah lingkungan gaul remaja yang hedonis, hura-hura dan cenderung mengarah ke hal-hal negatif. ${ }^{31}$

\footnotetext{
${ }^{28}$ Wawancara dengan Sri Rabiatul, pada tanggal 22 April 2019 bertempat di Lingkungan Sekolah.

${ }^{29}$ Wawancara dengan Andi Ainun Annisa, Ketua Komunitas Jofis (Jomblo Fii Sabilillah) Bulukumba, pada tanggal 27 Maret 2019 bertempat di Natural Cafe Bulukumba.

${ }^{30}$ Wawancara dengan Andi Ainun Annisa, pada tanggal 27 Maret 2019 bertempat di Natural Cafe Bulukumba.

${ }^{31}$ Najib Kailani" Kepanikan Moral dan Dakwah Islam Populer (Membaca Fenomena "Rohis" di Indonesia” Analisis XI, no. 1 (2011): 14.
}

Al Qalam: Jurnal Ilmiah Keagamaan dan Kemasyarakatan Vol. 15, No. 2 Juli-Desember 2021 
Pengaruh-pengaruh ini juga, karena implikasi dari kegiatan tarbiyah, ta'lim dan halaqah yang diikuti oleh pelajar atau siswa di luar lingkungan sekolah. Pengajianpengajian yang ikuti oleh siswa di Bulukumba, umumnya disalurkan kepada pengajian yang difasilitasi oleh Wahdah Islamiyah Bulukumba. Di mana gerakan dakwah dari Wahdah Islamiyah umumnya bercorak puritan.

\section{Materi pendidikan keagamaan yang diterima oleh siswa SMAN dan MAN di Bulukumba}

Dalam suatu pembelajaran, materi bukanlah merupakan tujuan, tetapi sebagai alat untuk mencapai tujuan. Olehnya itu, penentuan materi pengajaran harus didasarkan pada tujuan, baik dari segi cakupan, tingkat kesulitan maupun organisasinya. ${ }^{32}$ Secara generik, materi Pendidikan Agama Islam di SMAN dan Madrasah Aliyah itu berbeda. Dalam kurikulum 2013 di Kemendikbud, materi yang ada dalam buku PAI dan Budi Pekerti diajarkan selama 3 jam pelajaran per minggu saja. Sedangkan dalam kurikulum 2013 Madrasah Aliyah di Kemenag, terdapat empat mata pelajaran yang dikategorikan berada dalam rumpun PAI, yaitu Al-Qur'an Hadis, Akidah Akhlak, Fikih, dan Sejarah Kebudayaan Islam (SKI). Keempat mata pelajaran itu masing-masing diajarkan selama 2 jam pelajaran per minggu.

Materi PAI yang diterima oleh siswa di luar kelas baik siswa di SMA dan Madrasah Aliyah yang ada di Bulukumba. Data lapangan penulis, mengungkap materimateri kajian keagamaan yang mereka sering terima para pelajar di luar sekolah mereka. Sri Rabiatul mengatakan bahwa materi yang diikutinya adalah materi tentang adab, keutamaan berdoa dan hijrah. Sri juga memahami bahwa "hijrah" itu perpindahan atau proses perubahan, misalnya dulu tidak berhijab kemudian berhijab. Selain itu, misalnya berjauhan dengan lawan jenis atau yang bukan muhrim.

Bagi Farhan, dituturkan bahwa syarat untuk masuk pengurus Rohis adalah harus "Hijrah" terlebih dahulu. Menurutnya hijrah itu harus meninggalkan sesuatu yang dilarang oleh Allah swt. Tandanya adalah mengikuti kegiatan Tarbiyah dan Ta'lim. ${ }^{33}$ Ahmad Faizal justru lebih mencontohkan "hijrah" itu semacam memperbaiki diri. Misalnya, perampok atau pencuri kemudian berubah menjadi ustadz. Materi yang dijumpai oleh Nisa juga menyinggung tentang berhijrah, belajar caramah, dan belajar bahasa arab juga.

Dalam penelusuran penulis, kajian anak Rohis di MAN 1 Bulukumba, mengangkat tema tentang "Valentine's Day dalam pandangan Islam" siswa disuguhkan bagaimana dampak buruk dari "Hari Valentine" yang banyak membudaya di kalangan milenial. Terkait dengan materi-materi dalam literatur atau buku yang digunakan oleh siswa atau pelajar di sekolah maupun madrasah. Masih di pandang memuat

\footnotetext{
${ }^{32}$ Chabib Thoha, Saifuddin Zuhri, Syamsuddin Yahya, Metodologi Pengajaran Agama (Cet. II; Yogyakarta: IAIN Walisongo kerjasama Pustaka Pelajar, 2004), 16.

${ }^{33}$ Wawancara dengan Farhan, mantan ketua Rohis MAN 2 Bulukumba pada tanggal 27 Maret 2019 di Mesjid Miftahul Ulum Jl. Matahari Bulukumba.
}

Al Qalam: Jurnal Ilmiah Keagamaan dan Kemasyarakatan Vol. 15, No. 2 Juli-Desember 2021 
kecenderungan inklusif, alasannya karena kejelasan dan keberpihakan pemerintah terhadap visi pendidikan sebagai koekosistensi sosial keagamaan, termasuk Muslim dan Non Muslim di Indonesia. ${ }^{34}$

Namun, bagi penulis materi-materi "Hijrah" yang diterima oleh kalangan pelajar, akan membawa dampak kepada sikap ekslusivisme di kalangan pelajar. Apalagi tren "hijrah" masa kini, telah menjadi wacana kosmopolitan yang banyak menimbulkan ragam penafsiran. Apalagi kajian-kajian tentang "hjirah" telah menyasar kalangan pelajar.

Konsep hijrah sangat sentral dalam wacana Islamisme. Konsep ini menginginkan bahwa menjadi "muslim saja" tidaklah cukup, sehingga seseorang harus "berhijrah" menjadi Muslim yang taat dan "utuh", Muslim yang bergerak dan berkomitmen pada jalinan persaudaraan Muslim universal atau Muslim yang berani menanggalkan ideologi, budaya, dan nilai yang "tidak Islami”. Anak muda dan bahkan orang dewasa perkotaan yang merasa frustrasi dengan pola hidup materialis dan liberal pada titik tertentu akan tersentuh dengan doktrin hijrah. Doktrin hijrah menjanjikan pelakunya dengan hidup yang lebih berarti, pahala, dan surga. ${ }^{35}$

Tidak hanya itu, Rohis berhasil memainkan perannya sebagai sebuah representasi gerakan Islam kalangan pelajar., misalnya mengajak kalangan siswa untuk menghindari perayaan hari "Valentine", menghindari pacaran dan menjadi "Jomblo Fii Sabillah". Menjadi bukti bahwa, aktivitas dakwah sekolah begitu efektif.

\section{Sumber Belajar Pendidikan Islam siswa SMA/MA di Kabupaten Bulukumba}

Rusman, mengemukakan bahwa sumber belajar adalah segala bentuk atau segala sesuatu yang ada di luar diri seseorang yang bisa digunakan untuk membuat atau memudahkan terjadinya proses belajar pada diri sendiri atau peserta didik, apapun bentuknya, apapun bendanya, asal bisa digunakan untuk memudahkan proses belajar. ${ }^{36}$ Lebih spesifik AECT (Association of Education and Communication Technology), menjabarkan enam jenis yang dikategorikan sebagai sumber belajar, yaitu pesan (massege), orang (person), bahan (material), alat (device), teknik (technique), dan lingkungan (setting). ${ }^{37}$

Siswa atau peserta didik saat ini, tidak lagi monoton dalam memanfaatkan sumber belajarnya. Temuan penulis, terkait sumber belajar yang banyak digunakan atau dimanfaatkan oleh siswa di SMAN dan MAN di Bulukumba, cukup bervariasi. Namun, dari beragam varian sumber belajar siswa, namun ada 3 hal yang mendominasi sebagai sumber belajar yang aktif digunakan oleh siswa untuk belajar agama Islam. Varian

\footnotetext{
${ }^{34}$ Noorhaidi Hasan (ed), Literatur Keislaman Generasi Milenial: Transmisi, Apropsiasi dan Kontestasi, (Cet. II; Yogyakarta: Pascasarjana UIN Sunan Kalijaga Press, 2018), 60.

${ }^{35}$ Noorhaidi Hasan (ed), Literatur Keislaman Generasi Milenial: Transmisi, Apropsiasi dan Kontestasi..., 72.

${ }^{36}$ Rusman, Belajar dan Pembelajaran: Berorientasi Standar Proses Pendidikan..., 89.

${ }^{37}$ Lihat Karwono dan Heni Mularsih, Belajar dan Pembelajaran Serta Pemanfaatan Sumber Belajar, (Depok: Rajawali Pers, 2017), 159. Lihat juga Sudjarwo, Bebererapa Aspek Pengembangan Sumber Belajar, (Jakarta: PT Mediyatama Sarana Perkasa, 1989), 141-142.
}

Al Qalam: Jurnal Ilmiah Keagamaan dan Kemasyarakatan Vol. 15, No. 2 Juli-Desember 2021 
sumber belajar itu, antara lain: pertama, guru atau ustadz, kedua, buku atau literatur dan ketiga adalah media sosial. Inilah yang penulis akan uraikan pada bagian ini.

\section{Guru/Ustadz}

Posisi guru, kini tidak lagi menjadi satu-satunya sebagai sumber informasi. Tetapi, guru hanya berada pada bagian dari ragam sumber belajar yang tersedia saat ini. Perkembangan global yang diiringi dengan pesatnya perkembangan teknologi dan informasi dan hadirnya media baru menggeser peran utama guru.

Pergembangan yang begitu pesat juga dibidang pendidikan, berdampak pada teori "tabularasa" dari Jhon Locke yang cukup lama menjadi acuan dalam pendidikan di masa lalu. Siswa tidak lagi diibaratkan sebagai "kertas putih", dan guru tidak lagi menjadi satusatunya unsur luar yang menulisi "kertas putih". Kemudian dalam pendidikan, dikenal "teacher centered" yakni pembelajaran yang berpusat kepada guru. Kini telah bergeser kepada "student centered" yang berpusat kepada siswa.

Namun, dalam hal belajar agama sepertinya ini siswa masih tetap membutuhkan guru. Salah seorang siswa bernama Andi Akram Bakti ${ }^{38}$, menuturkan bahwa dirinya jarang belajar agama di sosial media. Menurutnya lebih baik langsung menghadiri pengajian. Pengajian yang biasa diikutinya adalah dalam bentuk tarbiyah yang diajarkan oleh murabbi. Juga sering mengikuti halaqah di salah satu mesjid di Bulukumba di mana yang mengisi pengajian itu adalah Ustadz Bahri, S.Pd. yang dalam penelusuran penulis Ustadz Bahri adalah ketua PD HILMI Bulukumba yang berafiliasi dengan organisasi Wahdah Islamiyah Bulukumba.

Informan lain, $\mathrm{Nisa}^{39}$ mengatakan bahwa dirinya biasa mengikuti pengajian di taman kota yang dilakukan oleh organisasi Majelis Dai Mudah Bulukumba setiap hari Jumat, saya belajar mengaji dan mendengarkan ceramah-ceramah agama di situ. Narasumber dalam pengajian ini, diisi oleh para dai muda yang berada di Bulukumba yang tergabung di dalam organisasi ini.

Berbeda halnya dengan Sri Rabiatul ${ }^{40}$. Siswa yang aktif mengikuti kajian dalam bentuk tarbiyah dan ta'lim yang dilakukan oleh Wahdah Islamiyah ini, memberikan keterangan menarik. Ia berujar bahwa, ia tidak langsung percaya dengan ceramah yang didengarkannya di sosial media. Ia biasanya mengkonfirmasi langsung ke ustadz saat mengikuti kajian Tarbiyah, bahwa kalau saya yakin maka saya coba melaksanakannya.

\section{Buku/Literatur}

Sumber belajar selanjutnya adalah buku atau literatur dapat dikategorikan sebagai bahan (material). Dalam wawancara penulis dengan informan yang berasal dari kalangan pelajar SMA/MAN di Bulukumba, penulis tidak menemukan buku/literatur khusus yang digunakan dalam aktivitas belajar siswa utamanya di luar sekolah. Hanya komunitas Jofis, yang menunjukkan referensi terkait dari motivasi mereka mendakwahkan "Jomblo Fii

\footnotetext{
${ }^{38}$ Wawancara dengan Andi Akram Bakti, pada tanggal 22 April 2019 bertempat di Mesjid Sekolah.

${ }^{39}$ Wawancara dengan Nisa, pada tanggal 09 April 2019 bertempat di lingkungan sekolah.

${ }^{40}$ Wawancara dengan Sri Rabiatul, siswa Kelas XI MIA 6 SMAN 1 Bulukumba pada tanggal 22 April 2019 bertempat di Lingkungan Sekolah.
}

Al Qalam: Jurnal Ilmiah Keagamaan dan Kemasyarakatan Vol. 15, No. 2 Juli-Desember 2021 
Sabillah", yaitu buku yang berjudul "Indonesia Tanpa Pacaran yang ditulis oleh Laode Munafar.

Selain itu, siswa pada umumnya menggunakan buku atau literatur Pendidikan Agama Islam yang disediakan oleh sekolah. Di mana mereka menggunakan buku itu, saat jam pelajaran agama berlangsung, setelah pembelajaran usai. Buku harus dikembalikan lagi ke perpustakaan sekolah. Aturan ini berlaku di sekolah SMAN dan MAN yang menjadi objek penelitian ini.

Di kurikulum 2013, ada dua jenis buku yang disediakan yaitu buku guru dan buku siswa ini berlaku pada semua jenjang utamanya di SMA dan MA. Buku siswa untuk mata pelajaran Pendidikan Agama Islam pada sifatnya hanya untuk digunakan dilingkungan sekolah. Tidak untuk dimiliki secara langsung oleh siswa, karena buku ini pulalah yang digilir ke siswa kelas lain untuk digunakan. Buku PAI dan Budi Pekerti yang diajarkan di SMAN 1 dan SMAN 8 Bulukumba itu sediakan oleh sekolah, yang anggaran penyediannya menggunakan anggaran dana BOS (Bantuan Operasional Sekolah), begitu juga yang terjadi di MAN 1 Bulukumba dan MAN 2 Bulukumba, anggaran pengadaaan buku juga dari dana BOS.

Penulis menemukan keragaman literatur PAI dan Budi Pekerti yang digunakan oleh siswa di SMAN 1 Bulukumba dan SMAN 8 Bulukumba. Untuk SMAN 1 Bulukumba, digunakan literatur PAI dan Budi Pekerti dari 2 Penerbit yang berbeda. Untuk kelas X dan Kelas XI, buku PAI dan Budi Pekerti yang digunakan oleh siswa diterbitkan oleh Erlangga. Perusahaan yang berpusat di Jakarta Timur ini, memiliki cabang perusahaan di Bulukumba. Buku PAI dan Budi Pekerti yang diterbitkan pada tahun 2013 itu ditulis oleh Sadi dan M. Nasikin. Sedangkan, buku PAI dan Budi Pekerti yang digunakan di kelas XII itu menggunakan terbitan Kementerian Pendidikan dan Kebudayaan (Kemendikbud) cetakan ke-1 tahun 2015 dan cetakan ke-2 edisi revisi tahun 2018. Buku ini ditulis oleh Sholeh Dimyathi dan Feisal Ghozali.

Berbeda halnya dengan buku PAI dan Budi Pekerti yang digunakan oleh siswa di SMAN 8 Bulukumba. Buku PAI dan Budi Pekerti yang digunakan berasal dari 2 penerbit yang berbeda. Untuk kelas X digunakan 2 buku PAI dan Budi Pekerti, yaitu buku yang berasal dari Kemendikbud yang ditulis oleh Nelty Khaeriyah dan Endi Suhendi Zen pada tahun 2016 dan buku yang ditulis oleh Rahmat Kamal tahun 2014 kemudian diterbitkan oleh Platinum asal Surakarta. Untuk kelas XI, juga digunakan 2 buku PAI dan Budi Pekerti, yaitu buku dari Kemendikbud yang ditulis oleh Mustahdi dan Mustakim pada tahun 2017 dan buku yang diterbitkan oleh Global pada tahun 2013. Untuk kelas XII, digunakan buku PAI dan Budi Pekerti dari Kemendikbud yang ditulis oleh Sholeh Dimyathi dan Feisal Ghozali pada tahun 2018. Namun, perlu diketahui bahwa penerbit Platinum dan Global adalah grup dari PT Tiga Serangkai Pustaka Mandiri.

Untuk literatur di tingkatan Madrasah Aliyah itu ada 4 mata pelajaran yang masuk dalam rumpun PAI, yaitu Al-Qur'an Hadis, Akidah Akhlak, Fikih dan Sejarah Kebudayaan Islam (SKI). Buku yang digunakan oleh siswa kelas X, XII dan XII pada MAN 1 Bulukumba untuk mata pelajaran Al-Qur'an Hadis, Akidah Akhlak, Fikih dan

Al Qalam: Jurnal Ilmiah Keagamaan dan Kemasyarakatan Vol. 15, No. 2 Juli-Desember 2021 
Sejarah Kebudayaan Islam. Semuanya telah mengunakan buku yang telah diterbitkan oleh Kementerian Agama RI. Namun, penulis juga menemukan buku yang diterbitkan oleh PT. Karya Toha Putra Semarang untuk buku mata pelajaran Al-Qur'an Hadis yang ditulis oleh Thoyib Sah Saputra dan Wahyudin tahun 2015, Akidah Akhlak di tulis oleh Moh. Matsna tahun 2015 dan Fikih ditulis oleh Djenjen Zainuddin tahun 2015 pada Kelas X di MAN 1 Bulukumba.

Buku yang sama juga penulis temukan pada MAN 2 Bulukumba, siswa kelas X, XII dan XII memakai buku mata pelajaran Al-Qur'an Hadis, Akidah Akhlak, Fikih dan SKI yang diterbitkan oleh Kementerian Agama RI. Penulis, juga menemukan buku yang diterbitkan oleh Erlangga dengan judul "Ayo Mengkaji Akidah dan Akhlak untuk MA Kelas X" buku ini ditulis oleh Usman dan Ida Inayahwati yang terbit pada tahun 2014. Selain itu di MAN 2 Bulukumba, penulis juga menemukan buku "Pengamalan Fikih 3" digunakan di kelas XII. Buku ini ditulis oleh M. Rizal Qosim yang diterbitkan oleh Aqila tahun 2017. Aqila adalah anak perusahaan dari PT. Tiga Serangkai Pustaka Mandiri yang terletak di Solo.

\section{Media Sosial}

Penyebaran dakwah Islam atau informasi tentang seputar Islam menjalar ke ranah sosial media ini. Hal ini sejalan dengan pesatnya perkembangan teknologi informasi dan situs-situs jejaring sosial yang dapat digunakan di ponsel pintar (smartphone). Ada banyak varian sosial media, yang menyuguhkan konten-konten dakwah yang dapat diakses dengan mudah dan lebih praktis.

Di kalangan siswa SMAN dan MAN di Bulukumba, lebih cenderung menggunakan aplikasi sosial media Youtube untuk belajar agama. Hal ini dapat dilihat dari beberapa wawancara penulis dengan informan yang juga aktif di organisasi Rohis di sekolahnya.

Menurut Yudha Purnama ${ }^{41}$, saya biasanya belajar agama dengan mendengarkan ceramah agama dari ustadz Hannan Attaki di sosial media, pakai aplikasi Youtube. Kalau belajar agama di Youtube lebih mudah, karena bisa memilih materi ceramah yang disukai. Sedangkan, kalau di sekolah itu terfokus pada satu materi. Sama halnya dengan Farhan $^{42}$ menyebutkan ustadz favoritnya yang sering dilihatnya di youtube seperti ustadz Adi Hidayat, Abd. Somad, Khalid Basalamah dan Safiq Basalamah.

Youtube memberikan pengaruh yang signifikan dalam memperkenalkan serta memberi pengaruh positif terhadap dakwah Islam. sosial media khususnya youtube telah menjadi lahan untuk meyebarkan dakwah Islam, karena masyarakat apalagi kalangan pelajar lebih tertarik untuk mengenal dan mengatasi rasa keingintahuannya melalui media sosial. Hampir semua elemen masyarakat yang justru belajar agama Islam melalui internet atau media sosial terutama youtube dibandingkan dengan datang langsung ke tempat

\footnotetext{
${ }^{41}$ Wawancara dengan Yudha Purnama, pada tanggal 25 April 2019 bertempat di lingkungan sekolah.

${ }^{42}$ Wawancara dengan Farhan, pada tanggal 27 Maret 2019 di Mesjid Miftahul Ulum Jl. Matahari Bulukumba
}

Al Qalam: Jurnal Ilmiah Keagamaan dan Kemasyarakatan Vol. 15, No. 2 Juli-Desember 2021 
diadakannya kajian Islam. Kemajuan teknologi semakin pesat, bagaikan raksasa, yang berlari cepat dan mereka yang tidak bisa mengikutinya akan tertinggal jauh dan dilibas oleh zaman. ${ }^{43}$

Remaja dan sosial media seperti dua sisi mata uang yang tidak bisa dipisahkan, selalu berkaitan dan erat antara satu sama lain. Ketika dunia teknologi informasi dan media komunikasi semakin berkembang, sosial media muncul sebagai trendsetter disemua kalangan, terutama remaja. Sampai-sampai orang nomor satu di negeri ini pun tidak mau ketinggalan untuk memiliki akun facebook dan twitter sebagai bentuk media komunikasinya.

Keberadaan media sosial itu memang menuntut masyarakat tidak terkecuali para peserta didik untuk mengikuti trend perkembangan jaman khususnya di bidang komunikasi. Tetapi apabila perkembangan teknologi tidak digunakan sebagaimana mestinya, dengan kata lain hanya sebatas trend dan digunakan untuk hal-hal yang tidak baik, tentunya akan berdampak pada tindakan-tindakan asusila. Bahkan, keberadaan teknologi ini juga bisa membuat orang kecanduan dan asyik berada dalam kehidupan dunia maya. ${ }^{44}$

Data di atas, memberikan informasi bahwa sumber belajar agama Islam siswa atau peserta didik itu ada 2 (dua), pertama, yaitu sumber belajar yang tersedia di sekolah kemudian menjadi bacaan dari siswa dalam kegiatan pembelajaran formal yang merujuk kepada Kurilukum 2013 di lingkungan sekolah baik yang digunakan oleh Sekolah Menangah Atas (SMA) dan Madrasah Aliyah (MA) di Bulukumba. Kedua, sumber belajar agama Islam yang diperoleh siswa dari luar sekolah, yakni melalui: 1) Guru/ustadz yang banyak berkontribusi dari dalam memberikan pengajian dalam bentuk tabligh akbar, tarbiyah, ta'lim dan halaqah yang berlangsung di luar kegiatan pembelajaran di sekolah. Hanya saja, pengajian-pengajian yang menjadi rujukan beberapa siswa lebih cenderung merujuk kepada pengajian yang dilakukan oleh organisasi Wahdah Islamiyah Bulukumba yang lebih cenderung merujuk kepada ajaran salafi lewat gerakan purifikasi.

Jalinan kerjasama Rohis dan HILMI, memunculkan saling kebergantungan. Di mana HILMI mampu melakukan negosiasi, untuk mengakitkan kajian keagamaan di sekolah dengan menawarkan penceramah-penceramah yang berafiliasi dari Wahdah Islamiyah. Menarik siswa atau pelajar untuk mengikuti kajian keagamaan yang dilakukan oleh Wahdah Islamiyah di luar sekolah. Peluang ini, akan memungkinan terjadi transmisi wacana-wacana purifikasi yang dilakukan oleh Wahdah Islamiyah dan akan mudah langsung diterima oleh kalangan pelajar yang haus akan ilmu agama.

Sedangkan, 2) sosial media. Kemudahan mengakses sosial media utamanya youtube kini telah menjadi media baru sebagai sumber informasi serta sumber belajar

\footnotetext{
${ }^{43}$ Randy Ramadhan \& Henny Destiana, "Pengaruh Media Sosial Youtube terhadap Perkembangan Dakwah Islam dengan Metode Structural Equalition Modeling (SEM)”, Sinkron 1, no. 3 (2018), 60-66.

${ }^{44}$ Edi Suryadi, M. Hidayat Ginanjar, M. Priyatna, "Penggunaan Sosial Media Whatsapp Dan Pengaruhnya terhadap Disiplin Belajar Peserta Didik pada Mata Pelajaran Pendidikan Agama Islam (Studi Kasus Di SMK Analis Kimia YKPI Bogor)" Edukasi Islam 7, no. 1 (2018): 3.
}

Al Qalam: Jurnal Ilmiah Keagamaan dan Kemasyarakatan Vol. 15, No. 2 Juli-Desember 2021 
agama yang lebih praktis yang dikemas lebih elegan dan mengasikkan bagi penontonnya. Dampaknya adalah, kalangan pelajar di Bulukumba begitu menggemari dan mengidolakan ustadz digital friendly. Seperti, Ustadz Abdul Shomad, Adi Hidayat, Hannan Attaki, Khalid Basalamah, Safiq Basalamah, Hawariyyun.

Kehadiran ustadz digital friendly ini, akan menjadi guru bagi pelajar di virtual space (ruang virtual). Yang mana pelajar lebih bebas, memilah-milih materi keagamaan yang disenanginya, termasuk meneguhkan keyakinan beragamanya. Hasil penelitian di Manado, mengapa ustadz Digital Friendly begitu disukai karena para penceramah tersebut dianggap lebih menarik dalam hal penyampaian materi, tafsir atas dalil-dalil yang disampaikan mudah dimengerti, jelas, tidak terlalu rumit dan sangat menghibur. ${ }^{45}$

\section{KESIMPULAN}

Potret aktivitas belajar siswa di Sekolah dan Madrasah di Bulukumba, menunjukkan upaya Islamisasi yang berlangsung pada ruang publik sekolah dan madrasah. Hal tersebut didominasi oleh aktivitas dakwah Islam yang digerakkan oleh organisasi Rohis (Rohani Islam). Rohis, cukup berhasil mengembangkan dakwah sekolah lewat beberapa program, seperti MABIT (Malam Bina Iman dan Taqwa), tarbiyah, ta'lim, tabligh akbar di sekolah.

Upaya tersebut sangat terlihat pada kalangan pelajar khususnya di SMA/MA di Kabupaten Bulukumba. Hal tersebut, terlihat jelas pada SMAN 1 Bulukumba, SMAN 8 Bulukumba, dan MAN 2 Bulukumba. Aktivitas belajar, materi pelajaran dan sumber belajar dari para pelajar, berimplikasi dengan munculnya "linguistic piety" atau kesalehan berbahasa yang ditunjukkan oleh aktivis Rohis yang dalam berkomunikasi mereka menggunakan kata-kata, seperti "ikhwan, akhwat, akhi, ukhti, antum, afwan" atau identik dengan Bahasa Arab. Hal berbeda yang terjadi pada MAN 1 Bulukumba, organisasi "Rohis" tidak ditemukan di sekolah ini. Namun, memiliki nama organisasi yaitu SISPAIS (Siswa Pencinta Agama Islam) yang kegiatannya cukup berbeda dengan "Rohis" yang dijumpai pada sekolah lainnya.

Di sisi lain, ini juga mencirikan sebagai bentuk ekspresi "hijrah" mereka yang kemudian menjadi populer sebagai bahan kajian yang pada umumnya mereka jumpai dalam bentuk kajian-kajian keislaman di luar sekolah lewat kegiatan tarbiyah, ta'lim dan halaqah. Pengaruh ceramah ustadz digital friendly juga berdampak kepada siswa yang aktif menggunakan sosial media, seperti youtube, instagram, whatsapp dan lainnya. Gejala ini menampilkan ekspresi yang bisa dikatakan mengalami hibridasi pada kalangan remaja, di mana mereka menjadi Islami tetapi tetap mengikuti budaya konsumtif sebagai anak muda yang akrab dengan ponsel pintar (smartphone).

\footnotetext{
${ }^{45}$ Chalder S. Bamualim, Hilmar Latief dan Irfan Abubakar (Ed), Kaum Muda Muslim Milenial; Konservatisme, Hibridasi Identitas, dan Tantangan Radikalisme, (Cet. I; Tangerang Selatan: CSRC UIN Syarif Hidayatullah Jakarta, 2018), 92.
}

Al Qalam: Jurnal Ilmiah Keagamaan dan Kemasyarakatan Vol. 15, No. 2 Juli-Desember 2021 
Andi Muhammad Asbar : Potret Aktivitas Belajar, Materi Pelajaran dan Sumber Belajar Pendidikan Agama Islam Siswa SMAN dan MAN di Bulukumba

\section{DAFTAR PUSTAKA}

Bamualim, Chalder S., Hilmar Latief dan Irfan Abubakar (Ed), Kaum Muda Muslim Milenial; Konservatisme, Hibridasi Identitas, dan Tantangan Radikalisme. Cet. I; Tangerang Selatan: CSRC UIN Syarif Hidayatullah Jakarta, 2018.

Hasan, Noorhaidi (ed), Literatur Keislaman Generasi Milenial: Transmisi, Apropsiasi dan Kontestasi. Cet. II; Yogyakarta: Pascasarjana UIN Sunan Kalijaga Press, 2018.

Hamalik, Oemar. Proses Belajar Mengajar, Cet. IV; Jakarta: Bumi Aksara, 2005.

https://hilmi.or.id/melalui-mabit-rohis-man-2-bulukumba-bentuk-generasi-pelanjut/

(Diakses pada tanggal 30 Maret 2019).

https://hilmi.or.id/allahu-akbar-ribuan-peserta-padati-tabligh-akbar-sekaliguspengukuhan-pengurus-pd-hilmi-bulukumba/ (Diakses pada tanggal 30 Maret 2019).

Kailani, Najib. "Kepanikan Moral dan Dakwah Islam Populer (Membaca Fenomena "Rohis" di Indonesia" Analisis XI, no. 1 (2011): 1-16.

Karwono dan Heni Mularsih, Belajar dan Pembelajaran Serta Pemanfaatan Sumber Belajar. Depok: Rajawali Pers, 2017.

Majid, Abdul dan Dian Andayani, Pendidikan Agama Islam Berbasis Kompetensi. Bandung: PT Rosdakarya, 2005.

Milles, Mattew B. and A. Michael Huberman, Qualitative Data Analysis: A Sourcebook Of New Methods. London: Sage Publication, 1984.

Mulyana, Rohmat. Mengartikulasikan Pendidikan Nilai. Bandung: Alfabeta, 2004.

Nasution, Metode Penelitian Naturalistik Kualitatif. Bandung: Tarsito, 2003.

Permana, Ahmad Norma \& Najib Kailani, Islam and the 2009 Indonesia Elections, Political and Cultural Issues: The Case of the Prosperous Justice Party (PKS). Bangkok: IRASEC, 2010.

Raihani, Pendidikan Islam dalam Masyarakat Multikultural. Yogyakarta: Pustaka Pelajar, 2016.

Ramadhan, Randy \& Henny Destiana, "Pengaruh Media Sosial Youtube terhadap Perkembangan Dakwah Islam dengan Metode Structural Equalition Modeling (SEM)", Sinkron 1, no. 3 (2018): 60-66.

Rusman, Belajar dan Pembelajaran: Berorientasi Standar Proses Pendidikan, Jakarta: Pranadamedia Group, 2017.

Suhadi, et al., Politik Pendidikan Agama: Kurikulum 2013 dan Ruang Publik Sekolah. Yogyakarta: Serial Laporan Kehidupan Beragama di Indonesia CRCS UGM, 2014.

Sudjarwo, Bebererapa Aspek Pengembangan Sumber Belajar. Jakarta: PT Mediyatama Sarana Perkasa, 1989.

Suryadi, Edi., M. Hidayat Ginanjar, M. Priyatna, "Penggunaan Sosial Media Whatsapp Dan Pengaruhnya terhadap Disiplin Belajar Peserta Didik pada Mata Pelajaran Pendidikan Agama Islam (Studi Kasus Di SMK Analis Kimia YKPI Bogor)" Edukasi Islam 7, no. 1 (2018): 1-21

Thoha, Chabib., Saifuddin Zuhri, Syamsuddin Yahya, Metodologi Pengajaran Agama. Cet. II; Yogyakarta: IAIN Walisongo kerjasama Pustaka Pelajar, 2004.

Widiantoro, Nogroho., Panduan Dakwah Sekolah, Kerja Besar untuk Perubahan Besar. Bandung: Syaamil Cipta Media, 2003.

Al Qalam: Jurnal Ilmiah Keagamaan dan Kemasyarakatan Vol. 15, No. 2

Juli-Desember 2021 